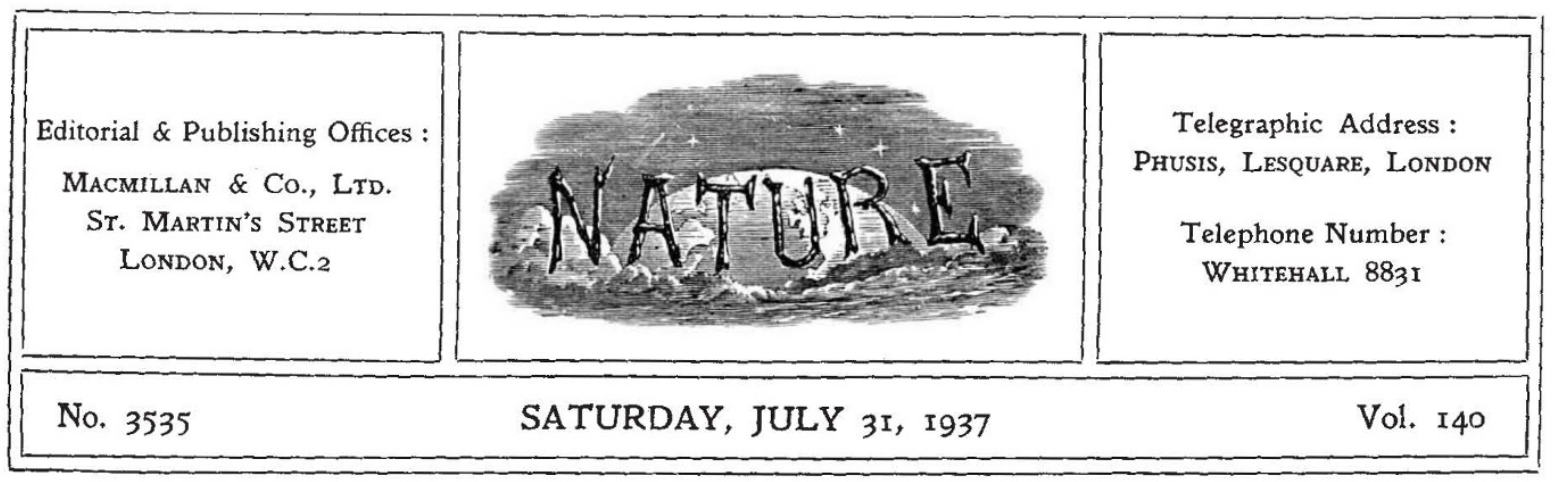

\title{
Freedom of Science and Learning
}

$S^{0}$ much has been said recently upon the $S$ subjects of academic freedom and intellectual liberty that there is a tendency for the terms to become catchwords, as in the much-used phrase "Poverty in the midst of plenty". If this were the main result of the reiteration of the principle that scientific inquiry can only develop to its full extent in an atmosphere of political freedom, it might reasonably be suggested that there has been too much talk about liberty but too little done to secure it. Fifty years ago, as Prof. Hogben reminded us in his Conway Memorial Lecture"The Retreat from Reason"--T. H. Huxley, in an address on technical education, used the pregnant words "The great end of life is not knowledge but action"; and this principle may be applied very appropriately to the reaction that has resulted from a knowledge of conditions deliberately created to restrict scientific work to particular classes, and thus to destroy the international character of the pursuit of scientific truth.

The group of British scholars and scientific workers who, under the leadership of Lord Rutherford, formed the Academic Assistance Council in 1933 wished to defend the principles of university freedom by actions rather than words. As the Council's report*, which has recently been published, says, the Council has relied on the propaganda of practical achievement, not of protest or agitation. The achievement disclosed by the report is remarkable. Of the approximately 800 refugee University teachers from Germany, 465 are permanently re-established and 320 have been provided with temporary positions enabling them

Third Report of the Academic Assistance Council (Society for the Protection of Science and Learning, 6 Gordon Square, London, W.C.1). Copies may be obtained gratis on application to the Genera Secretary of the Society. to continue their scientific work. This work has been accomplished during a period of economic depression, which has weakened the absorptive capacities of the universities and increased national protectionist activities in the learned professions of all countries. The report emphasizes that the Council itself is directly responsible for only a part of this achievement; the Council is the institutional expression of a spontaneous activity in the university world to assist the displaced scholars. It is, therefore, the index of a great co-operative achievement by the free universities, the success of which, in contrast to the relatively unsatisfactory progress made towards a solution of the refugee problem in general, proves that it depends chiefly not on motives of compassion but on convictions that the principle of university freedom is involved, and is implicitly defended by assistance for the refugee scholars.

The report is a demonstration of how vigorous is the determination to defend liberty. The work in itself has strengthened that liberty. University teachers, co-operating in the work of academic assistance which the Council has kept consistently on a basis of political neutrality, and associating with the exiles who have suffered by the destruction of liberty, must have learned during the past four years to value more highly the practical advantages of their own freedom. Furthermore, the proof that in a crisis men of science can rely upon the moral and effective support of their colleagues in other countries must have increased that security which is a condition of freedom. It cannot be hoped that the leaders of intolerance and irrationalism will be deterred by the knowledge that their victims will be sheltered in the asylum of liberal countries; but we may hope that 
their opponents will feel slightly more secure in their opposition, and we shall be spared a repetition of what still remains the most tragic feature of the German disaster, the absence of any stubborn resistance by the universities themselves to the restriction of their freedom.

The report makes it clear that university teachers in several countries will need all possible moral encouragement in face of the widening menace to the security of learning. Realizing this, the Academic Assistance Council has converted itself into a more permanent organization, the Society for the Protection of Science and Learning. The dismissal of university teachers in Germany on 'racial' grounds has seen two main phasesthat after the original legislation of 1933 and that after the Nuremberg legislation in the autumn of 1935. Information in the last few weeks suggests that a third phase is beginning; for a considerable number of professors have recently been dismissed merely because they have Jewish wives. Parallel with the series of dismissals on 'racial' grounds there has been a continuing process of dismissals on grounds of 'political unreliability'. The law of January 21, 1935, providing for a 'fundamental reconstruction of the universities' has been used for arbitrary dismissals when the other regulations did not provide so convenient a pretext. The report gives details of the displacement of scholars in other countries on grounds of religious or political opinion ; for example, in Italy, Portugal and the U.S.S.R., and of the beginnings of a refugee movement from Spain in consequence of the civil war. The Society considers that its services are even more necessary to-day than when the Academic Assistance Council was founded in May 1933.

It may be asked why Great Britain should take a leading part in this work of salvaging scholarship wrecked by the subjection of universities within the new authoritarian States, and whether the work is worth while. On grounds of principle, there can be little doubt that our tradition of toleration imposes on us a special responsibility, and that it is justifiable in defending principles to protect those who have been victimized by the nonrecognition of those principles. Doubts arise, however, not on theoretical grounds but on practical considerations. The Society's report describes fully its methods of work and convincingly answers the possible criticism that the sheltering of the refugees in Great Britain has injured the interests of British university teachers by pointing out that its work has "protected them from the injury that was threatened in the situation in 1933 when an army of wandering scholars invaded the university world, without guidance or directed distribution, and when no new financial resources were available with which the universities could meet the crisis" It is pointed out that, for the future, the efficiency of the work in re-establishing the scholars will make it necessary for almost all to be assisted to re-establishment in over-seas countries without even a period of sojourn here. We must keep a sense of proportion in this matter. There are 228 German émigré scholars in Great Britain, and it cannot be seriously claimed that they threaten the professional interests of the 6,000 British university teachers. During the past four years, the Council alone has added a sum of $£ 65,000$ to the resources of the universities, which has enabled them to bear the additional strain so unexpectedly imposed.

Hospitality is a two-way process, and it is evident how greatly the universities have profited from their guests. One of the German men of science who had found asylum in the United States was urgently invited by Herr Rust to return to Germany, where his ancestry would be forgiven because his services were required in the rearmament programme. He declined the invitation, expressing the hope that Herr Rust would succeed within ten years in benefiting the German universities as much as he had benefited the American universities within one year. It is rumoured that a certain institution not far from Camibridge has considered the advisability of erecting a tablet in gratitude for the benefactions bestowed on it by the results of the new National Socialist régime. The pages of Nature itself almost each week show how much of the learning and talent that was threat. ened with extinction in Germany in 1933 has been preserved through the agency of bodies like this Society.

In the gloomy pages of the history of the German universities in the last four years, this work of the Society for the Protection of Science and Learning stands out in happy relief. The Council asks for continued support for its activities and hopes that many will associate themselves with the work by becoming members of the Society. Few subscriptions to societies can show such good profit as a guinea membership subscription to this Society, which is trying to protect science and learning. 